Institute of $\mathbf{F}_{\text {ood and }} \mathbf{A}_{\text {gricultural }} \mathbf{S}_{\text {ciences }}$

\title{
Atala, Atala Hairstreak, Coontie Hairstreak, Eumaeus atala Röber (Insecta: Lepidoptera: Lycaenidae) ${ }^{1}$
}

Donald W. Hall and Jerry F. Butler²

\section{Introduction}

The atala is our largest and most spectacular eastern U.S. hairstreak. Due to decline in abundance of its host plant, coontie, because of over-harvest (as a source of starch) and habitat destruction due to development, the atala was believed to have become extinct. It was not collected in Florida from 1937 until 1959. The atala is now common locally in southeast Florida probably as a result of the popularity of its host plant as a landscape ornamental. In fact, it is now occasionally considered a pest in ornamental plant nurseries.

\section{Distribution}

In the U.S., the atala is found only in tropical southeastern Florida.

\section{Description}

The wingspread is 20 to $24 \mathrm{~mm}$. The upper surface of the front wings of males is black around the margins with the central area metallic green. Upper surfaces of front wings of females are black with a dusting of iridescent blue on median areas. The upper surface of the hind wings of both sexes is black with a sub-marginal row of green spots in males and blue spots in females. The sub-marginal spots in males are narrow dashes whereas those in females are more broad and triangular in shape. The undersides of the hind wings are black with three rows of blue spots and a bright red-orange spot on the mid-caudal border. The abdomen is bright red-orange.

Larvae are bright red-orange and have a double row of yellow spots that run dorsally nearly the length of the larva.

Pupae are brown or orange-brown with small dark spots and are supported by a silken girdle. The cuticle is covered with droplets of a bitter-tasting liquid. Pupae stridulate.

\section{Life Cycle}

There are many flights throughout much of the year. Both males and females generally stay in the vicinity of the host plants. Adults have a slow, fluttering flight and sip nectar from flowers primarily during early morning and late afternoon. Resting

1. This document is EENY-169, one of the Featured Creatures series of the Entomology and Nematology Department, Cooperative Extension Service, Institute of Food and Agricultural Sciences, University of Florida. Published: October 2000. This document is also available on Featured Creatures Website at http://creatures.ifas.ufl.edu. Please visit the EDIS Website at http://edis.ifas.ufl.edu. Additional information on these organisms, including many color photographs, is available at the Entomology and Nematology Department website at http://entnemdept.ifas.ufl.edu/.

2. Donald W. Hall, professor, and Jerry F. Butler, professor, Entomology and Nematology Department, University of Florida, Gainesville, FL.

The Institute of Food and Agricultural Sciences (IFAS) is an Equal Employment Opportunity - Affirmative Action Employer authorized to provide research, educational information and other services only to individuals and institutions that function without regard to race, creed, color, religion, age, disability, sex, sexual orientation, marital status, national origin, political opinions or affiliations. For information on obtaining other extension publications, contact your county Cooperative Extension Service office. Florida Cooperative Extension Service / Institute of Food and Agricultural Sciences / University of Florida / Larry R. Arrington, Interim Dean 


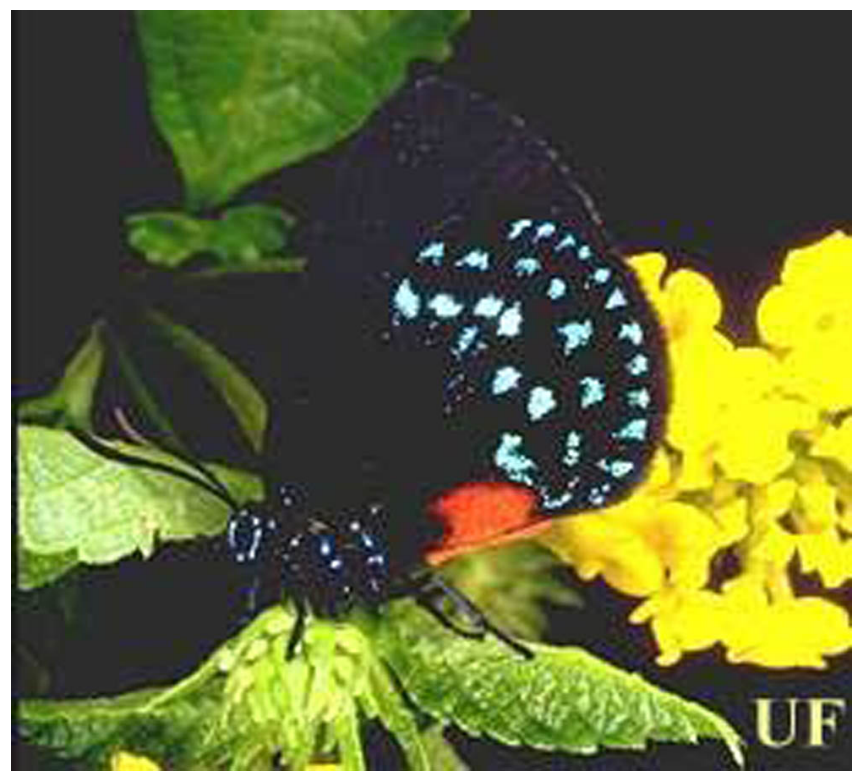

Figure 1. Lower surface of an adult female atala, Eumaeus atala Röber. Credits: Jerry F. Butler, University of Florida

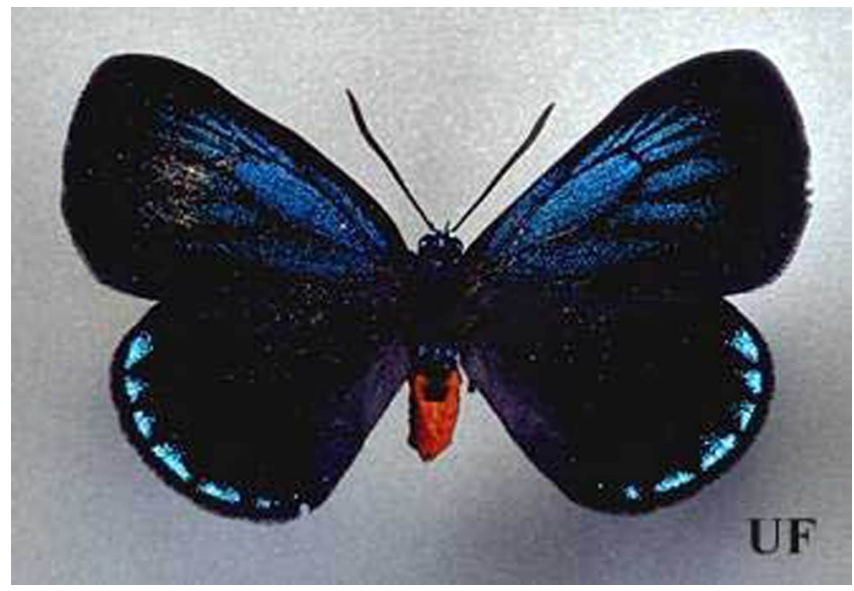

Figure 2. Upper surface of an adult female atala, Eumaeus atala Röber. Credits: Jerry F. Butler, University of Florida

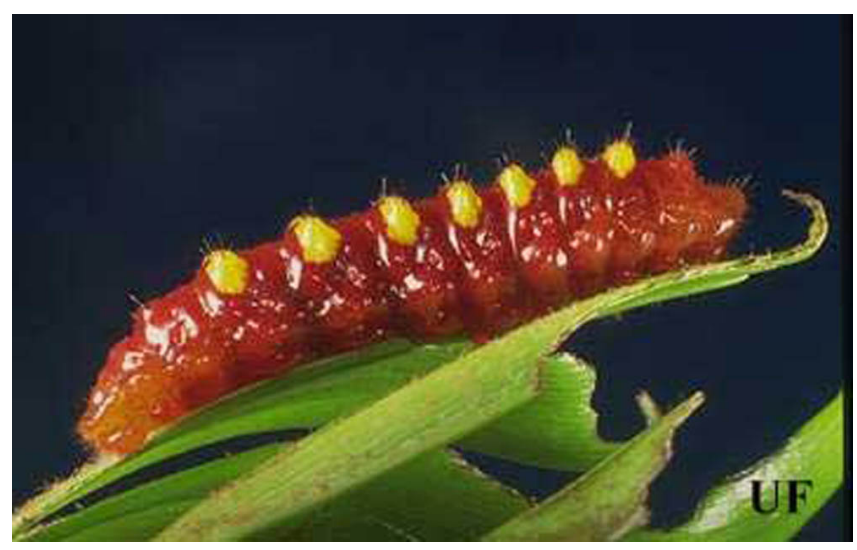

Figure 3. Larva of the atala hairstreak, Eumaeus atala Röber. Credits: Jerry F. Butler, University of Florida

adults are not readily disturbed and may often be touched.
The grayish white eggs are typically laid in groups on the tips of new leaves of the host plant -especially seedlings. After a 1995 fire management experiment in a rock-land pine forest in Everglades National Park, newly leafed-out foliage of coontie was severely defoliated by atala larvae while there was no defoliation of cooties in unburned areas. Bright orange scales from the anal tuft of the adult female surround the egg batch. A few larval spines are incorporated into this adornment of bright scales. Larvae often feed in groups.

The only native host plant is the cycad, coontie or Florida arrowroot, Zamia pumila Linnaeus (Zamiaceae), but females have been observed to oviposit readily on a variety of exotic species of Zamia as well as a few cycads of other genera.

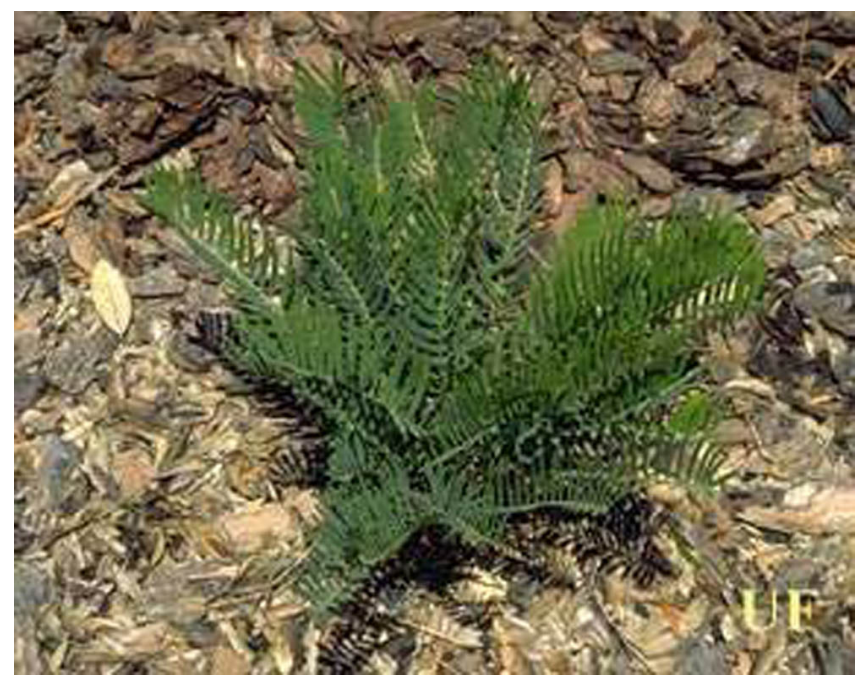

Figure 4. Coontie, Zamia pumila Linnaeus. Credits: Jerry F. Butler, University of Florida

The atala is a great example of aposematic (warning) coloration throughout its life cycle. Its host, Zamia pumila is laced with the toxic secondary plant chemical cycasin with greatest concentrations in the new foliage favored by atala larvae. As it feeds the larva stores the cycasin in its tissues. The cycasin is retained throughout the pupal and adult stages rendering all three stages distasteful and toxic to predators. In adult atalas, the cycasin is distributed equally between the body and wings.

The appearance and biology of the atala are typical of many chemically defended insects. Most aposematic insects advertise the fact that they are dangerous with bright contrasting colors. Also, they 
often are found in aggregations. It is likely that the bright red-orange scales that are placed around the atala eggs and possibly the eggs themselves contain cycasin. By aggregating, the bright red-orange and yellow larvae enhance their warning coloration. A predator tasting one of them will most likely leave the others alone. The iridescent greens and blues on the wings, the red-orange abdomens, and the red-orange spots on the hind wings of the adults are also conspicuous warnings to would-be predators. Even the slow flight of adults and their reluctance to fly when disturbed are characteristic of many aposematic insects.

\section{Selected References}

Baggett, H.D. 1982. Florida atala. In: Franz, R., ed., Rare and Endangered Biota of Florida. Vol. 6. Invertebrates. University Presses of Florida. Gainesville, Florida. Pp. 75-77.

Bowers, M.D. and Z. Larin. 1989. Acquired chemical defense in the lycaenid butterfly Eumaeus atala Journal of Chemical Ecology 15: 1133-1146.

Bowers, M.D. and S. Farley. 1990. The behaviour of grey jays, Perisoreus canadensis, towards palatable and unpalatable Lepidoptera. Animal Behaviour 39: 699-705.

Culbert, D.F., (October 1995). "Florida coonties and atala butterflies." UF/IFAS Featured Creatures. http://edis.ifas.ufl.edu/MG347. (November 6, 2000).

Gerberg, E.J. and R.H. Arnett. 1989. Florida Butterflies. National Science Publications, Inc. Baltimore, MD.

Hammer, R.L. 1996. New food plants for Eumaeus atala in Florida. News of the Lepidopterists' Society 38: 1.

Landolt, P.J. 1984. The Florida atala butterfly, Eumaeus atala florida Rueber (Lepidoptera: Lycaenidae), in Dade County, Florida. Florida Entomologist 67: 570-571.

Minno, M.C. and T.C. Emmel. 1993. Butterflies of the Florida Keys. Scientific Publishers.

Gainesville, Florida.
Negrón-Ortiz, V. and D.L. Gorchov. 1996. Effect of fire season on Zamia pumila L. in pinelands of Everglades National Park, FL: preliminary findings. American Journal of Botany 83(6): 85. Abstract \#245.

Opler, P.A. and G.O. Krizek. 1984. Butterflies East of the Great Plains. The Johns Hopkins University Press. Baltimore, MD.

Opler, P.A. and V. Malikul. 1998. Eastern Butterflies. Peterson Field Guide Series. Houghton Mifflin Company. New York.

Rawson, G. 1961. The recent rediscovery of Eumaeus atala (Lycaenidae) in Florida. Journal of the Lepidopterists' Society 15: 237-244.

Rothschild, M. 1992. Egg protection by the atala hairstreak butterfly (Eumaeus atala florida).

Phytochemistry 31: 1959-1960.

Rothschild, M. 1986. Cycasin in the endangered butterfly Eumaeus atala florida. Phytochemistry 25: 1853-1854.

Scott, J.A. 1986. The Butterflies of North America. Stanford University Press. Stanford, CA. 